\title{
Sero-prevalence status of foot and mouth disease in the North Western Amhara Regional State, Ethiopia
}

\author{
${ }^{1}$ Abbishu Tesfaye ${ }^{2}$, Araya Mengistu ${ }^{3 *}$ and Tesfaye Rufael ${ }^{3}$ \\ ${ }^{1}$ Faculty of Veterinary Medicine, University of Gondar, Gondar, Ethiopia \\ ${ }^{2}$ Oromia Livestock and Fishery Resource Development Beraue, Oromia, Ethiopia \\ ${ }^{3}$ National Animal Health Diagnostic and Investigation Center (NAHDIC), Sebeta Ethiopia \\ ${ }^{*}$ Corresponding Author: National Animal Health Diagnostic and Investigation Center (NAHDIC), \\ P.O. Box 04, Sebeta, Ethiopia, E-mail: chibssasafo@gmail.com \\ http://dx.doi.org/10.4314/evj.v20i2.4
}

\begin{abstract}
A cross-sectional survey was conducted on serum samples collected from North and South Gondar zones of North Western Amhara Regional State, Ethiopia to determine the sero-prevalence of foot and mouth diseases in bovine species. The samples were processed with the nonstructural protein (NSP) enzyme linked immunosorbent assay (ELISA) that can able to differentiate foot and mouth disease (FMD) naturally infected vaccinated animals. From the total sera tested, the overall sero-prevalence of foot and mouth disease in cattle at the North and South Gondar zones was $14.9 \%$ (86/578). The prevalence rate was high in North Gondar, $17.8 \%$ (66/370), as compared to $9.6 \%(20 / 208)$ in South Gondar and the difference was statistically significant $\left(x^{2}=7.108, p=0.008\right)$. Highest sero-prevalence was observed at Metema (62.5\%), Quara (46.7\%) and Alefa Takusa (34.9\%) districts of North Gondar zone, which are bordering with Sudan. The difference among the districts is also statistically significant $\left(\mathrm{X}^{2}=141.115, \mathrm{p}=0.0001\right)$. There was also a significant association between seropositivity and age groups $\left(\mathrm{X}^{2}=9.483, \mathrm{P}=0.009\right)$ but there was no significant association between the seropositivity and sex $\left(X^{2}=0.623\right.$, $p=0.430)$. This information on sero surveillance of foot and mouth disease in cattle is important for further epidemiological studies towards developing effective foot and mouth disease control strategies, particularly in these areas where animal movement is not restricted.
\end{abstract}

Keywords: Cattle, Seroprevalence, FMD, North West Amhara Region, 3ABC ELISA 


\section{Introduction}

Foot and mouth disease (FMD) is a highly contagious acute viral infection of cloven hoofed animals including domesticated ruminants and pigs and more than 70 wildlife species and is one of the most important economic diseases of livestock (Sutmoller et al., 2003; Coetzer et al., 1994; Broonsvoort et al., 2004). The disease is characterized by fever, loss of appetite, salivation and vesicular eruptions in mucosa of the mouth, skin of the inter-digital spaces and coronary bands of the feet and teats. It is also characterized by high morbidity and low mortality (Coetzer et al., 1994). It is caused by the genus Aphthovirus, in the family Picornaviridae of which seven distinct serotypes O, A, C, SAT1, SAT2, and SAT 3 and Asia 1 are known (Belsham, 1993).

FMD is endemic in most countries in sub Saharan Africa with six of the seven serotypes reported to occur in East Africa namely O, A, C, SAT 1, SAT 2 and SAT 3 thus complicating the epidemiology and control of the disease in the region. Serotype SAT 3 has been recorded only in Uganda (Vosloo et al., 2002).

The disease is endemic in Ethiopia and currently four of the serotypes; namely $\mathrm{O}, \mathrm{A}, \mathrm{SAT} 1$ and SAT2 are circulated in all regions of the country (Gelagy Ayelet et al., 2009; Tesfaye Rufael et al., 2012). Foot and mouth disease is one of the major trans-boundary animal diseases (TADs) that impact negatively on trade of livestock and livestock products in all the regions of Ethiopia. In order to prevent and/or control the disease in the targeted areas, a good understanding of disease epidemiology is important and this can only happen if the disease is traced and regular and effective surveillances are carried out (FAO, 2005, 2006).

Infection with any one serotype of FMD does not confer immunity against the other serotypes (Rweyemamu et al., 20080). The disease spreads rapidly by movement of infected animals or mechanically on formites such as clothing, shoes, vehicles and veterinary instruments (Sumption et al., 2008). The reasons for the rapidity of the spread to fully susceptible populations is due to the highly infectious nature of the virus, the production of high titer in respiratory secretions, the large volumes of droplets and aerosols of virus shed by infected animals, the stability of virus in such droplets, the rapid replication cycle with very high virus yields and the short incubation period (Sellers, 1971). 
Nonstructural protein (NSP) enzyme linked immune sorbent assay (ELISA) test is useful because it is able to discriminate the animals that have been infected from those that have been vaccinated. Such test would be able to detect continued viral circulation and would therefore be extremely useful for serological surveys with a view to control (Clavijo et al., 1994). FMD is one of the most economical important diseases for livestock development in Ethiopia, particularly for poor farmers and animal export trade. Thus, the present study was conducted to determine the sero-prevalence of FMD in the North and South Gondar zones of North West Amhara regional State, which can serves as a base line data for developing control strategy plan in the region.

\section{Materials and Methods}

\section{Study area and study animals}

The study was conducted in North and South Gondar administrative zones, which are located in South West of Amhara Regional State, Ethiopia and share international boundaries with Sudan where the Dinder national park is located as well as Tigray and Benishangul Gumuz Regional States of Ethiopia. We purposely selected two zones from the survey areas in which the districts were proportionately distributed among the selected zones according to the cattle population. Nine of the districts from North Gondar areas namely; Quara, Metema, Alefa Takusa, Dembia, Debark, Janamora, Tach Armacho, Gondar Zuria and W/Belesa and eight districts from South Gondar namely Estie, Simada, Lay Guynt, Farta, Ebnat, Libokemkem, Fogera and Dera were included. The survey was conducted on cattle that were kept under extensive production system.

\section{Study design and sampling method}

Across-sectional study was conducted from November, 2008 to March, 2009 to determine the seroprevalence of FMD in North West Amhara Regional State. During the field work a total of 578 cattle were randomly selected from herds of North and South Gondar Zones. The sample size required for the study was determined based on the expected prevalence of FMD according to the formula given by Thrustfield (1995). There is no previous prevalence study on FMD in the study areas. Therefore using the $50 \%$ prevalence as expected prevalence $95 \%$ confidence interval and 5\% absolute precision, the number 
of study animal's were 384 as calculated below and in order to improve the precision, the sample size was increased by two folds were considered from the study areas

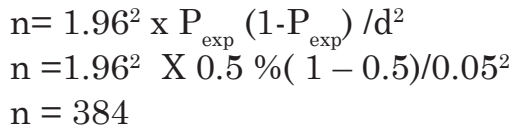

\section{Sample collection and submission}

From the total 578 animals included for the study, 370 and 208 of cattle were from Northern and Southern Gondar zones, respectively. Blood samples were collected using sterile plain vaccutainer tubes and allowed to clot by placing it over night at room temperature. The serum was decanted carefully from the clotted blood and transported using a whynter 45QT portable fridge/ freezer to the National Animal Health Diagnostic and Investigation Center (NAHDIC), Sebeta, and labeled with unique laboratory identification number. The sera samples then stored at negative $20^{\circ} \mathrm{C}$ until laboratory investigation is undertaken.

\section{Laboratory examination}

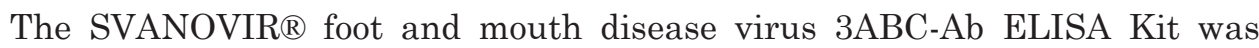
used to detect FMD virus specific antibodies in bovine serum samples. The kit procedure was based on a solid phase indirect ELISA. In this procedure, samples were exposed to non-infectious FMD virus antigen (NSP 3ABC) coated wells on microstate plates. FMD virus antibodies (if present in the test sample) bind to the antigen in the well. HRP conjugate added subsequently forms a complex with the FMD virus antibodies. Unbound materials removed by washing (rinsing) before the addition of substrate solution. Subsequently a blue-green color were develops, which is due to the conversion of the substrate by the conjugate. The reaction stopped by the addition of stoping solution. The result was read by a micro plate photometer, where the optical density (OD) was measured at $405 \mathrm{~nm}$. 


\section{Data analysis}

The data collected was entered into Microsoft (Ms) excel spread sheet program and coded for analysis. The laboratory result was analyzed using SPSS statistical packages for social sciences. Variation of the prevalence between the two different Zones of Gondar, (North Gondar and South Gondar) was analyzed by using chi-square $\left(\mathrm{X}^{2}\right)$ test. In all the analysis, confidence level was at $95 \%$ and $\mathrm{P}<0.05$ set for significance.

\section{Results}

The seroprevalence result of 578 bovine sera sample from North and South Gondar of Amhara Regional State were assessed for the presence of nonstructural FMD virus protein (antibodies). The overall seroprevalence of FMD in cattle at the North and South Gondar zones was 14.9\% (86/578) (Table 1). The prevalence rate was high in North Gondar 17.8\% (66/370) as compared to 9.6\% (20/208) in south Gondar. The difference in the prevalence between the two zones were significant association $\left(\mathrm{x}^{2}=7.108, \mathrm{p}=0.008\right)$.

Table 1: Seroprevalence of FMD in cattle of North and South Gondar zones, 2008-2009

\begin{tabular}{lcccc}
\hline Zones & $\begin{array}{c}\text { Number of } \\
\text { samples }\end{array}$ & $\begin{array}{c}\text { Number of } \\
\text { positive }\end{array}$ & $\begin{array}{c}\text { Number of } \\
\text { negatives }\end{array}$ & Seroprevalence (\%) \\
\hline North Gondar & 370 & 66 & 304 & 17.8 \\
South Gondar & 208 & 20 & 188 & 9.6 \\
Total & 578 & 86 & 492 & 14.9 \\
\hline
\end{tabular}

The seroprevalence results of FMD at district level are given in Table 2. The highest seroprevalence was observed at Metema (62.5\%) followed by Quara (46.7 \%) and AlefaTakusa (34.9\%) districts of North Gondar and FMD virus antibody was not detected in Tach Armacho and Gondar Zuria (North Gondar) and Estie districts (South Gondar zone). The difference among districts was statistically significant $\left(\mathrm{X}^{2}=141.115, \mathrm{p}=0.000\right)$. 
Abbishu Tesfaye et al.,

Table 2: Proportion of FMD Sero prevalence in cattle at district levels in the study zones, 2008-2009

\begin{tabular}{|c|c|c|c|c|c|}
\hline Zones & Districts & $\begin{array}{c}\text { Number of } \\
\text { samples }\end{array}$ & $\begin{array}{l}\text { Number of } \\
\text { positive }\end{array}$ & $\begin{array}{l}\text { Number of } \\
\text { negative }\end{array}$ & $\begin{array}{c}\text { Seroprevalence } \\
(\%)\end{array}$ \\
\hline \multirow[t]{9}{*}{ North Gondar } & Quara & 30 & 14 & 16 & 46.7 \\
\hline & Metema & 32 & 20 & 12 & 62.5 \\
\hline & AlefaTakusa & 63 & 22 & 41 & 34.9 \\
\hline & Dembia & 81 & 6 & 75 & 7.4 \\
\hline & Debark & 32 & 1 & 31 & 3.1 \\
\hline & Janamora & 66 & 1 & 65 & 1.5 \\
\hline & Tach Armacho & 17 & 0 & 17 & 0.0 \\
\hline & Gondar Zuria & 15 & 0 & 15 & 0.0 \\
\hline & W/Belesa & 34 & 2 & 32 & 5.9 \\
\hline \multirow[t]{8}{*}{ South Gondar } & Estie & 64 & 0 & 64 & 0.0 \\
\hline & Simada & 32 & 5 & 27 & 15.6 \\
\hline & Lay Guynt & 32 & 2 & 30 & 6.3 \\
\hline & Farta & 16 & 1 & 15 & 6.3 \\
\hline & Ebnat & 16 & 3 & 13 & 18.8 \\
\hline & LiboKemkem & 16 & 2 & 14 & 12.5 \\
\hline & Fogera & 15 & 4 & 11 & 26.7 \\
\hline & Dera & 16 & 3 & 13 & 18.8 \\
\hline Total & 17 & 578 & 86 & 492 & 14.9 \\
\hline
\end{tabular}

The seroprevalence rate of FMD in North and South Gondar Zones increases as the age group of the animals' increases. This result is indicated on the values in calves, young and adults were $8.1 \%$ (7/86), $9.9 \%(14 / 141)$ and 18.5 $\%(65 / 351)$, respectively (Table 3$)$. The difference is statistically significant $\left(X^{2}=9.483, P=0.009\right)$. 
Table 3: Seroprevalence of FMD in cattle at different age group in the study zones

\begin{tabular}{lcccc}
\hline \multicolumn{1}{c}{ Age group } & $\begin{array}{c}\text { Number of } \\
\text { Samples }\end{array}$ & $\begin{array}{c}\text { Number of } \\
\text { positive }\end{array}$ & $\begin{array}{c}\text { Number of } \\
\text { negative }\end{array}$ & Seroprevalence (\%) \\
\hline Calves (6 $6^{\text {th }}$-year) & 86 & 7 & 79 & 8.1 \\
Young (1-3year) & 141 & 14 & 127 & 9.9 \\
Adults (>3year) & 351 & 65 & 286 & 18.5 \\
Total & 578 & 86 & 492 & 14.9 \\
\hline
\end{tabular}

The seroprevalence between sex groups were also evaluated (Table 4). The sero-prevalence status in male and female was 13.6\% (34/251) and 15.9\% (52/327), respectively, indicating the difference is statistically insignificant $\left(\mathrm{x}^{2}=0.623, \mathrm{p}=0.430\right)$.

Table 4: Seroprevalence of FMD in Cattle at different sex groups in the study zones, 2008-2009

\begin{tabular}{lcccc}
\hline Age group & $\begin{array}{c}\text { Number of } \\
\text { Samples }\end{array}$ & $\begin{array}{c}\text { Number } \\
\text { of } \\
\text { positive }\end{array}$ & $\begin{array}{c}\text { Number } \\
\text { of } \\
\text { negative }\end{array}$ & Seroprevalence (\%) \\
\hline Male & 251 & 34 & 217 & 13.6 \\
Female & 327 & 52 & 275 & 15.9 \\
Total & 578 & 86 & 492 & 14.9 \\
\hline
\end{tabular}

\section{Discussion}

Even though the disease has been reported in the survey zone as well as in the region, the seroprevalence study of FMD in these zones was conducted for the first time. In this study the overall seroprevalence rate of FMD in North West Amhara Regional State was reported as $14.9 \%$ in individual animals. The seroprevalence of FMD virus in the present study was in agreement with the finding of Gebretsadik Zerabruk et al. (2009) who reported $15.4 \%$ seroprevalence in Tigray Regional State. The current study result was less prevalence from Tesfaye Rufael et al. (2008), who reported $21 \%$ in Burans pastoral system. The increase in the prevalence from the previous study may be associated to with the pastoral production system with nature of increased livestock movements that could result in high rate of contact between animals 
at common grazing places as well as at watering points (Tesfaye Rufael et al., 2008).

The seroprevalence of North Gondar zone was higher as compared to South Gondar zone, this is probably due to the fact that North Gondar zone of Amhara Region have long border with Sudan. This may be attributable to the free movement of cattle across national boundaries for grazing and watering as well as animal cross border trade.

The survey also revealed a significant association between seropositivity of FMD and age group of cattle in North West Amhara Region. Significantly higher seroprevalence in adults with $>2$ years of age as compared to that of calves with $<1$ year of age and young animals with 1 to 2 years of age which is inconsistent with other previous findings done in Ethiopia by Tesfaye Rufael et al. (2008) in Borena pastoral area and Bereket Molla et al. (2010) in Gamo Gofa and Sidama zones. On the other hand, the results were not in agreement with the findings of Esayas Gelaye et al. (2009) who carried out a research in Bench Maji zone, southern Ethiopia where they documented no significant association. This may be due to the fact that, those cattle with age group greater than four years had practiced more exposure to FMD during grazing, watering point and at market than in age group less than 2 years. The low prevalence in calves may be indicative of persistence of passive immunity and frequency of exposure as the farmers keep their calves around the village and therefore, calves had less chance of being infected by FMD virus than adults (Tesfaye Rufael et al., 2008).

There was no statistical significant association between seropositivity and sex of the animals which is in consistent with the previous findings elsewhere where sex group of animals did not have a significant effect on seropositivity of FMD (Esayas Gelaye et al., 2009; Bekele Megersa et al., 2009). On the contrary, in the reports on the incidence of FMD among dairy cattle in Northwest Ethiopia Hailu Mengiste et al. (2010) documented a higher incidence rate in female $(16.63 \%)$ cattle as compared to males (1.37\%). The preset study confirmed that both sexes have equal chance of getting infection by FMD. 


\section{Conclusion}

FMD is endemic in Ethiopia with variation in prevalence across several zones within the region. Movement of the herds sometimes across the borders in search of water and pasture and illegal livestock trade is one of the major factors that contribute to the contact of cattle and subsequent spread of FMD. The movement and intermingling of domestic and wild animals near the park is also one of the risk factor for FMD and should be addressed in programmes to prevent and control FMD in the affected Zones and Regional States in Ethiopia. It is recommended that seroprevalence surveys should be undertaken in wildlife and small ruminants so as to determine the role of these animals may play in the transmission of FMD in Ethiopia. Such surveys should be part of a systematic disease surveillance and data collection. It is also advised for strategic vaccination programmes using vaccination method with FMD serotype circulating in the region to reduce the prevalence FMD virus.

\section{Acknowledgements}

The authors would like to thank the National Animal Health Diagnostic and Investigation Center for provision of budget for the field work, reagents and kits during the research work.

\section{References}

Ayelet, G., Mahapatra, M., Gelaye, E., Egziabher, B. G., Rufeal, T., Sahle, M., .et al., 2009. Genetic characterization of foot-and-mouth disease viruses, Ethiopia, 19812007. Emerg. Infect. Dis., 15(9), 1409-1417.

Broonsvoort, M., Hamman, M., Tanya, N., Kitching, P. and Morgan, L., 2004. Risk factors for herdsman-reported foot and mouth disease in the Adamawa province of Cameroon. Prev. Vet. Med., 66,127-139

Clavijo, A., Zhou, E. M., Hole, K., Galic, B. and Kitching, P., 2004. Development and use of a biotinylated $3 \mathrm{ABC}$ recombinant protein in a solid-phase competitive ELISA for the detection of antibodies against foot-and-mouth disease virus. J. virol. Meth., $120(2), 217-227$.

Coetzer, W., Thomson, R. and Tustin, C., 1994. In Infectious diseases of livestock with special reference to Southern Africa. Infect. Dis. Livest., 2, 825-852. 
Esayas, G., Gelagay, A., Tsegalem, A. and Kassahun, A., 2009. Seroprevalence of foot and mouth disease in Bench Maji Zone Southwestern Ethiopia. Afr. J. Microb. Res., 5(21), 3559-3563

FAO, 2005-2006. Empres watch, Foot and Mouth disease situation worldwide and major epidemiological Events.Retrieved from http://www.fao.org/docs/eims/ upload/225050/focus-ON-1-07-en.pdf.

Zerabruk,G., Romha,G. and Rufael, T., 2014. seroepidemiological investigation of foot and mouth disease in cattle managed under extensive husbandry system in Tigray, Northern Ethiopia; Global Vet., 13, 112-116

Hailu, M., Mengistie, T., Negussie, H., Alemu, S. and Asaminew, T., 2010. Incidence of foot and mouth disease and its effect on milk yield in dairy cattle at Andassa dairy farm. Northwest Ethiopia. J. Agric. Biol., 1, 969-973.

Megersa, B., Beyene, B., Abunna, F., Regassa, A., Amenu, K. and Rufael, T., 2009. Risk factors for foot and mouth disease seroprevalence indigenous cattle in Southern Ethiopia: the effect of production system. Trop. Anim. Health Prod., 41, 891-898.

Molla, B., Ayelet, G., Asfaw, Y., Jibril, Y., Ganga, G. and Gelaye, E., 2010. Epidemiological study on foot and mouth disease in cattle: Seroprevalence and risk factor assessment in South Omo Zone, South-Western Ethiopia. Trans. Emerg. Infect. Dis., 57, 340-347.

Rufael, T., Catley, A., Bogale, A., Sahle, M. and Shiferaw, Y., 2008. Foot and mouth disease In the Borana pastoral system, southern Ethiopia and implication for livelihoods and international trade. Trop. Anim. Health Prod., 40, 29-38.

Rufael, T., Shale, M., Nemera, M., Muluneh, A., King, D., Paton, D., Siraw, B. and Hammond, J., 2012. Situation of foot-and-mouth disease in Ethiopia from 20102012, EUEMD; Appliance of science in the progressive control of FMD, Jerez de la Frontera, Spain..

Raouf, Y. A., Tamador, M. A. A., Nahid, A. I. and Shaza, M., 2012. A survey for antibodies against current infection of foot-and-mouth disease virus in Sudanese cattle, sheep and goats using neutralization test. Bul. Anim. Health Prod. Afr., 60(3), 351-358.

Rweyemamu, M., Roeder, P., Mackay, D., Sumption, K., Brownlie, J., Leforban, Y. and Saraiva, V., 2008. Epidemiological patterns of foot-and-mouth disease worldwide. Trans. Emerg. Dis., 55(1), 57-72.

Sellers, F., 1971. Quantitative aspects of spread of foot and mouth disease. Vet. Bul., 41, 431-439.

Sutmoller, P., Barteling, S. S., Olascoaga, R. C. and Sumption, K. J., 2003. Control and eradication of foot-and-mouth disease. Virus Res., 91(1), 101-144. 
Sumption, K., Rweyemamu, M. and Wint, W., 2008. Incidence and distribution of footand-mouth disease in Asia, Africa and South America combining expert opinion, official disease information and livestock populations to assist risk assessment. Trans. Emerg. Dis., 55(1), 5-13.

Vosloo, W., Bastos, S., Sangare, O., Hargreaves, K. and Thomson, R., 2002. Review of the status and control of foot and mouth disease in sub-Saharan Africa. OIE Sci. tech. Rev., 21(3), 437-447 